\title{
Impostor Phenomenon on First- and Second-year College Students
}

\author{
Ulimaz Dea Fahira, Bahrul Hayat \\ Faculty of Psychology, UIN Syarif Hidayatullah Jakarta \\ bahrulhayat@uinikt.ac.id
}

\begin{abstract}
New students tend to experience the stress and anxiety of transitioning from the school environment to the campus environment. Anxiety in dealing with new situations or roles can lead to the Impostor Phenomenon (IP). This study aimed to determine the effect of family relationships, general anxiety, and the Big-five personality traits on impostor phenomena. The sample of this study was 439 first and secondyear students taken by the non-probability sampling technique. The measuring instruments used in this research are Clance Impostor Phenomenon Scale (CIPS), Brief Family Relationships Scale (BFRS), Four-Dimensional Anxiety Scale (FDAS), and Big-five Inventory (BFI). Data analysis in this study used Confirmatory Factor Analysis (CFA) and multiple regression analysis techniques. The results showed a significant effect of family relationships, general anxiety, and the Big-five personality traits on the impostor phenomenon. Based on testing the minor hypothesis, there are six significant variables: emotional, physiological, cognitive, behaviour, extraversion, and awareness. Other variables such as cohesion, expressiveness, conflict, agreeableness, neuroticism, and openness have no significant effect on the impostor phenomenon.
\end{abstract}

Keywords: Impostor phenomenon, stress, anxiety, college students

\begin{abstract}
Abstrak
Mahasiswa baru cenderung mengalami stress dan kecemasan saat melakukan transisi dari lingkungan sekolah ke lingkungan kampus. Kecemasan dalam menghadapi situasi baru atau peran baru bisa mengarah kepada terjadinya Impostor Phenomenon (IP) atau fenomena impostor. Studi ini bertujuan untuk melihat pengaruh dari hubungan keluarga, kecemasan secara umum, dan kepribadian Big-Five terhadap fenomena impostor. Sampel dalam studi ini berjumlah 439 mahasiswa tahun pertama dan kedua dengan teknik pengambilan sampel non-probability. Instrumen yang digunakan untuk mengukur dalam penelitian ini adalah Clance Impostor Phenomenon Scale (CIPS), Brief Family Relationships Scale (BFRS), FourDimensional Anxiety Scale (FDAS), dan Big-five Inventory (BFI). Analisa data yang digunakan dalam penelitian ini adalah Confirmatory Factor Analysis (CFA) dan teknik analisis regresi berganda. Hasil menunjukkan adanya pengaruh signifikan dari hubungan keluarga, kecemasan secara umum, dan kepribadian Big Five terhadap fenomena impostor. Berdasarkan uji hipotesis minor, ada 6 variabel signifikan, yaitu: emosional, fisiologis, kognitif, perilaku, ekstraversi, dan kesadaran. Variael lainnya seperti kohesi, ekspresif, konflik, agreeableness, neuroticism, dan openness tidak menunjukkan adanya pengaruh signifikan terhadap fenomena impostor.
\end{abstract}

Kata Kunci: Fenomena Impostor, stres, kecemasan, mahasiswa 


\section{Introduction}

College students often experience pressures, both academically and psychologically. Especially for those who experience a role change and transition to a new situation, i.e., from a student to a college student. First- and second-year college students tend to experience more high anxiety levels than those in higher years (Baryam \& Bilgel, 2008; Farrer, Gulliver, Bennett, Fassnacht, \& Griffiths, 2016; Liu, Ping, $\&$ Gao, 2019). When they are facing a new competitive environment and high academic pressure, some of them will question their past competencies (Bernard, Dollinger, \& Ramaniah, 2002). Anxiety over the challenges of a new situation or role can lead to the impostor phenomenon (IP) (Parkman, 2016). This may happen due to the pressure of irrational thoughts, anxiety, self-doubt, and also avoiding failure because of high expectations (Chandra, Huebert, Crowley, \& Das, 2019; Dudău, 2014; Thompson, Davis, \& Davidson, 1997).

Impostor Phenomenon (IP) is a phenomenon that may be experienced by individuals who feel they are less intelligent, inexperienced, incapable, or not competent enough, thereby perceiving themselves as if they are a fraud (Clance \& Imes, 1978; Hawley \& Paul, 2019). According to Sightler and Wilson (2001), IP is an internal state in which individuals feel fraudulent because they perceive they are unworthy of their intelligence or accomplishments although they have achieved success. Feeling like a fraud or intellectual phonies refers to how individuals with IP intentionally or unintentionally fool others into thinking they are very intelligent or successful as people believe is central to the concept of impostorism or fraudulence (Leary, Patton, Orlando, \& Funk, 2000). Hawley dan Paul (2019) described IP as a phenomenon that involves an individual's negative perception of their abilities or competencies. The impact of IP creates barriers to performance optimization and self-actualization (Wulandari \& Tjundjing, 2007). Individuals who experience this phenomenon have the misconception of ideal success due to the need to be special and be the best (Sakulku \& Alexander, 2011). In addition, they also have fear of failure and avoid challenging tasks (Chandra et al., 2019). Impostor disregards their success when there is a gap between their actual performance and their ideal standard, which is why they tend to discount of positive feedback (Sakulku \& Alexander, 2011). They will experience pressure when they receive praise because they have to maintain their image as someone who deserves it, but ironically they consider their hard work just a matter of luck (McDowell, Boyd, \& Bowler, 2007).

Individuals who are experiencing IP have a lack of confidence about their abilities when confronted with new situations (McDowell et al., 2007). When they are dealing with new challenges and tasks with high standards, they will react in maladaptive ways such as perfectionism and procrastination which is characteristic of IP (Chandra et al., 2019). Self-doubt because of fear of failure and high expectations creates an image of them as a fraud or intellectual phonies because they worry that they are actually not capable or intelligent enough and afraid other people will find out (Hawley \& Paul, 2019). Although IP is not a type of mental disorder, but rather a phenomenon, IP can affect a person's psychological wellbeing, such as work, studies, interpersonal relationships, or ability to achieve self-actualization (Dudău, 2014). Self-doubts about their abilities will affect their academic and personal life aspects (Hoang, 2013).

Therefore, this phenomenon (impostor) becomes a mental health issue that should be addressed regarding the number of suicide cases in the campus area (Parkman, 2016). Some universities work with counselors, such as the University of California and MIT (Massachusetts Institute of Technology), who conduct IP prevention programs for new students that aim to help and support students to identify IP tendencies, identify strengths, and set reasonable expectations for themselves. (Cokley, McClain, Enciso, \& Martinez, 2013; Parkman, 2016).

One of the factors of IP is the emergence of high standards set by the family from childhood to adulthood (Clance, Dingman, Reviere, \& Stober, 1995). These standards make the relationships between the child and their parents inharmonious. Unrealistic expectations cause people to grow up without knowing their true talents and capabilities. Research on family relationships and IP originated from Bussotti's dissertation (cited by Sakulku and Alexander, 2011), she investigated that feelings of imposter arise from families and individuals who lack communication, have rule-controlled behavior, and are filled 
with conflict. Hawbam and Singh (2018) also showed that IP is negatively correlated with cohesiveness, expressiveness and positively correlated with conflict. Cohesion is one of the dimensions of family relationships in which families help and support each other (Fok, Allen, Henry, \& Team, 2014), while expressiveness measures the level to which family members behave liberally and openly express their feelings and thoughts toward each other (Fok, Allen, Henry, \& Team, 2014). Mirsu-Paun, 2004), and conflict according to Moos and Moos (cited by Sapp, 2003), how family members openly express their emotions, characterized by anger, aggression, and conflict with each other. According to Li et al. (2014) besides family relationships, children's roles, parenting styles, age, birth order, and gender are also important in strengthening and supporting the influence of family relationships on IP. Sonnak and Towell (2001) support this claim that the impostor has a significant effect on overprotective parenting styles.

Poor interpersonal relationships and high standards that have been set since childhood can lead to anxiety in individuals. This anxiety makes it difficult for people to believe in themselves and set other people's standards for them. Therefore, anxiety haunts them every day in every aspect. Anxiety that occurs every day in a general way is also known as generalized anxiety. Generalized anxiety is an anxiety disorder in all situations in both social and academic life that can affect emotions, thoughts, physical, and even behavior (Lobsang, Bystritsky, Dafter, \& Spearman, 2015). People who experience IP also feel anxiety in all situations (Bernard et al., 2002). Topping's research (cited by Langford and Clance, 1993) found a positive correlation between the impostor phenomenon and anxiety (trait anxiety). Kumar and Jagicinski (2006), who studied 135 college students, found that IP correlated positively with test anxiety and negatively with self-confidence. Farrer et al. (2016) students who feel excessive pressure to succeed, lack self-confidence, have difficulty coping with learning, procrastination, or have problems with time management are significantly associated with a risk for generalized anxiety disorder (GAD). IP can be caused by psychological pressures (such as anxiety, depression, burnout, depersonalization, and delayed achievement), behavioral (fatigue resulting from working too hard and avoiding tasks), cognitive (fixed mindset and refusal to accept positive feedback), and physiological (experiencing psychosomatic (pain in certain parts of the body or autonomic nerve disorders (sweating or digestive problems)) because they seek perfection and set standards too high (Bystritsky et al., 1990; Chandra et al., 2019; Clance and Toole, 1987).

One of the psychological factors that influence the impostor phenomenon is personality traits. According to Canning, LaCosse, and Kroeper (2019), the impact of the phenomenon on IP in competitive classes causes those who experience it to be less actively engaged in class, have a desire to drop out of school, and cause low grades. Nevertheless, this study also explained that IP is more due to the trait of the individual. This is also proven by the research of Bravata, et al. (2019) that there is no difference between the scores of students who experience the imposter phenomenon or not, the difference is personality traits. Several studies examined the Big-five personality traits towards IP. As a result, traits of neuroticism, namely negative emotions and low impulse control, are characteristics of IP and other personality traits, such as conscientiousness, extraversion, openness, and agreeableness are negatively correlated with IP (Bernard et al., 2002; Ross, Stewart, Mugge, \& Fultz, 2001; Vergauwe, Wille, Feys, Fruyt, \& Anseel, 2014). The conscientiousness trait is the most significant negative in IP (Bernard et al., 2002; Ross et al., 2001; Vergauwe et al., 2014). People with IP often experience burnout that leads to work procrastination due to lack of discipline and lack of competence to perform a task (Chandra et al., 2019). On the other hand, research by Rohrmann et al. (2016) showed a negative but non-significant correlation between conscientiousness and IP. In addition, trait extraversion is negatively significant with IP (Ross et al., 2001). While other studies showed that extraversion, openness, and agreeableness are not significant and have negative direction with IP (Bernard et al., 2002; Ross et al., 2001; Vergauwe et al., 2014).

Although this phenomenon can be experienced by anyone, this topic still needs more attention. IP is often considered as part of self-esteem, self-efficacy, or insecurity. According to Harvey and Katz (1985) they argued that self-esteem and insecurity are behavioral characteristics or feelings that are broad and nonspecific, unlike IP which focuses more on individual abilities and achievements. Although low self- 
efficacy also avoids tasks or situations, IP has other characteristics, namely luck, such as fraud-like (fake), and difficulty receiving and internalizing praise (discounted praise) (French et al., 2016). In Indonesia, this topic has not been widely conducted, although this phenomenon may be experienced by anyone. Therefore, research is needed to study and measure the factors that influence it (family relationships, generalized anxiety, and Big-Five personality traits).

\section{Methods}

The population in this study are college students in the first year and second year (second and fourth semesters) of both public and private universities in Java, Indonesia. In this study, we used a nonprobability sampling technique with online form questionnaire (Typeform) via social media from May to June 2020. The research measurement instruments we used were adapted to Indonesian language. For more information described in detail below:

1) Clance Impostor Phenomenon Scale (CIPS). This instrument was developed by Clance (1985) consists of 20 items. The reliability of CIPS is (Cronbach $=.90$ to .92) (Chrisman, Pieper, Clance, Holland, \& Hughes, 1995; Leary et al., 2000). This instrument had two dimensions (false/discount and luck) (French et al., 2016).

2) The Brief Family Relationships Scale (BFRS) was developed by Fok et al. (2011) consists of 16 Likert-scale items. This instrument consists of three dimensions (cohesiveness, expressiveness, and conflict). The reliability of the BFRS is (Cronbach $=.65$ to .92) (Fok et al., 2014; Nishihara, Belgian, Kim, Schmöcker, \& Axhausan, 2017).

3) Four-dimensional anxiety scale (FDAS). This instrument was developed by Bystritsky et al. (1990) consists of 35 items with four dimensions: emotional, physiological, cognitive and behavioral. The reliability of this instrument is (Cronbach = .92 to .93) (Bystritsky et al., 1990; Stoessel, Bystritsky and Pasnau, 1995).

4) Big-five Inventory (BFI). This instrument was developed by John, Naumann and Soto (2008) consists of 40 items with a Likert scale. It consists of five dimensions of extraversion, agreeableness, conscientiousness, neuroticism, and openness. Reliability property of BFI $($ Cronbach $=.83)($ John et al., 2008).

In this study, to test the validity of the instruments, we used Confirmatory Factor Analysis (CFA) to examine the unidimensional fit model of each instrument. Step two, we used multiple regression analysis (multiple regression analysis) to test the research hypothesis and also confirm the significance of independent variable on dependent variable.

\section{Result and Discussion}

\section{Research sample overview}

The sample of this research were 439 college students of public and private universities in their firstand second-year. The description of the sample described in detail according to genders, grades and fields in the following table 1.

Table 1. General description of the sample

\begin{tabular}{llll}
\hline & Research Sample & Frecuency & $\%$ \\
\hline Genders & & 96 & \\
a. Male & $34.86 \%$ \\
b. Female & & 343 & $78.13 \%$ \\
\hline
\end{tabular}




\begin{tabular}{lll}
\hline Grades & & \\
a. First-year & 259 & $59.00 \%$ \\
b. Second-year & 180 & $41.00 \%$ \\
\hline Fields & & \\
a. Economic and Business & 61 & $13.89 \%$ \\
b. Social and Humanities & 172 & $39.17 \%$ \\
c. Engineering & 53 & $12.07 \%$ \\
d. Medical, Mathematics, and Natural Sciences & 76 & $17.31 \%$ \\
e. Education & 77 & $17.53 \%$ \\
\hline
\end{tabular}

Based on the data in Table 1 above, the number of males sample were 96 subjects $(21.86 \%)$ and the number of females sample were 343 subjects (78.13\%). In conclusion, the majority of the sample in this study were females. In addition, the samples were in first-year (59.00\%) and second-year (41.00\%). Clearly, most of the samples who participated in this research were first-year students. There are 61 samples were majoring in Economics and Business (13.89\%) consisted of the Faculty of Economics and Business. Social and Humanities up to 153 (39.17\%) sample, which consisted of Faculty of Psychology, Faculty of Social and Political Sciences, Faculty of Law, Faculty of Da'wah and Communication Studies, and Faculty of Islamic Broadcasting. Engineering major up to 53 people (12.07\%) consisted of the Faculty of Engineering. Medical, Mathematics and Natural Sciences, up to 76 samples (17.31\%) were from the Faculty of Medicine, Faculty of Nursing, Faculty of Mathematics, and Natural Sciences and Faculty of Agriculture. Education field were 77 samples (17. 53\%) which consisted of Faculty of Educational Psychology, Faculty of Tarbiyah and Teaching Training, and the last is Faculty of Education in Social Sciences.

\section{Hypothesis test result}

Table 2. R Square Table

\begin{tabular}{lllll}
\hline & & \multicolumn{3}{c}{ Model Summary $^{\mathbf{b}}$} \\
\hline Model & $\mathrm{R}$ & R Square & Adjusted R Square & Std. Error of the Estimate \\
\hline 1 & $.649^{\mathrm{a}}$ & .421 & .405 & 7.26155 \\
\hline
\end{tabular}

a. Predictors: (Constant), Openness, Cognitive, Cohesion, Agreeableness, Conscientiousness, Behavior, Extroversion, Conflict, Physiological, Neuroticism, Expressiveness, Emotional

b. Dependent Variable: Impostor_Phenomenon

Table 2 presents R Square is .421 (42.1\%). Therefore, the proportion of variance of IP described by cohesion, expressiveness, conflict, emotional, physiological, cognitive, behavioral, extraversion, agreeableness, conscientiousness, neuroticism, and openness is $42.1 \%$, whereas the remaining $57.9 \%$ is influenced by variables outside this study.

Tabel 3. ANOVA Table

\begin{tabular}{|c|c|c|c|c|c|c|}
\hline \multicolumn{7}{|c|}{ ANOVA $^{\mathrm{a}}$} \\
\hline & Model & Sum of Squares & $\mathrm{df}$ & Mean Square & $\mathrm{F}$ & Sig. \\
\hline \multirow{3}{*}{1} & Regression & 16337.724 & 12 & 1361.477 & 25.820 & $.000^{\mathrm{b}}$ \\
\hline & Residual & 22463.046322 & 426 & 52.730 & & \\
\hline & Total & 38800.769872 & 438 & & & \\
\hline
\end{tabular}

a. Dependent Variable: Impostor_Phenomenon 
b. Predictors: (Constant), Openness, Cognitive, Cohesion, Agreeableness, Conscientiousness, Behavior, Extroversion, Conflict, Physiological, Neuroticism, Expressiveness, Emotional

Table 3 shows p-value (probability) in this study is 0.000 (sig. <0.05), means the hypothesis "There is no significant influence of family relationships (cohesiveness, expressiveness and conflict), generalized anxiety (emotional, physiological, cognitive, and behavioral) and the Big-five personality traits (extraversion, agreeableness, conscientiousness, neuroticism, and openness) to the impostor phenomenon" is rejected. This means, there is an overall influence of the independent variable on the dependent variable.

After finding out whether all the independent variables have a significant effect on the dependent variable, the next step is to examine the significance of the regression coefficients of each independent variable.

Table 4. Regression Coefficient

\begin{tabular}{|c|c|c|c|c|c|c|}
\hline \multicolumn{7}{|c|}{ Coefficients $^{\mathrm{a}}$} \\
\hline & \multirow{2}{*}{ Model } & \multicolumn{2}{|c|}{$\begin{array}{l}\text { Unstandardized } \\
\text { Coefficients }\end{array}$} & \multirow{2}{*}{$\begin{array}{l}\text { Standardized } \\
\text { Coefficients } \\
\text { Beta }\end{array}$} & \multirow{2}{*}{$\mathrm{t}$} & \multirow{2}{*}{ Sig. } \\
\hline & & $\mathrm{B}$ & Std. Error & & & \\
\hline \multirow[t]{13}{*}{1} & (Constant) & 30.641 & 5.795 & & 5.288 & .000 \\
\hline & Cohesion & -.018 & .061 & -.018 & -.298 & .766 \\
\hline & Expressiveness & -.017 & .058 & -.017 & -.292 & .770 \\
\hline & Conflict & .070 & .043 & .074 & 1.632 & .103 \\
\hline & Emotional & .202 & .064 & .187 & 3.156 & $.002 *$ \\
\hline & Physiological & .102 & .049 & .097 & 2.072 & $.039 *$ \\
\hline & Cognitive & .297 & .058 & .289 & 5.130 & $.000 *$ \\
\hline & Behavior & .143 & .052 & .121 & 2.760 & $.006^{*}$ \\
\hline & Extraversion & -.188 & .046 & -.179 & -4.105 & $.000^{*}$ \\
\hline & Agreeableness & -.001 & .049 & -.001 & -.014 & .989 \\
\hline & Conscientiousness & -.192 & .042 & -.180 & -4.306 & $.000^{*}$ \\
\hline & Neuroticism & -.019 & .059 & -.018 & -.326 & .745 \\
\hline & Openness & .008 & .044 & .008 & .192 & .848 \\
\hline
\end{tabular}

* significant

In conclusion, regression model in this study is Impostor Phenomenon $=30.641-0.018$ (cohesion) 0.017 (expressiveness) +0.074 (conflict) +0.187 (emotional)* +0.097 (physiological) $^{*}+0.289$ (cognitive) $^{*}+0.121$ (behavior) $^{*}-0.179$ (extraversion)* -0.001 (agreeableness) -0.180 (conscientiousness) $^{*}-0.018$ (neuroticism) +0.008 (openness) $+\mathrm{e}$.

Table 4 shows there are six significant variables $(p<0.05)$ namely emotional, physiological, cognitive, behavioral, extraversion and conscientiousness. Whereas, six variables, namely cohesiveness, expressiveness, conflict, agreeableness, neuroticism, and openness have weak influences.

From this finding, coefficients of each variable show that there is a significant correlation of impostor phenomenon with generalized anxiety variable (emotional, physiological, cognitive, and behavioral) and Big-five personality traits variable (extraversion and conscientiousness). Emotional, physiological, cognitive, and behavioral aspects of IP have a positive direction. We can conclude that the higher level of generalized anxiety in individuals, the more they are prone to impostor phenomenon. On the contrary, extraversion and conscientiousness aspects have a negative direction, it means the low levels of extraversion and conscientiousness, the more intense impostor experience. For further explanation described in each next paragraph. 
Emotional trait from generalized anxiety variable (see Table 4) in this study has a significant positive influence on IP. Individuals with higher emotional anxiety levels are more prone to impostor phenomenon. This is also supported by several studies showing that IP is caused by psychological stress that causes depression, burnout, anxiety, and excessive negative emotions (Chandra et al., 2019; Mennin et al., 2005; Thompson et al., 1997).

In addition, the results of the physiological aspect of the regression coefficient of the generalized anxiety variable in this study have a significant influence on IP. Thus, the more intense physiological anxiety in individuals, the greater they experience IP, as explained by Chandra et al. (2019) when a person is overworked along with anxiety, it leads to physical exhaustion, such as headaches, heart-pounding, going to the bathroom more frequently than usual, or sweating (Chandra et al., 2019).

The cognitive aspect of the generalized anxiety variable in this study has a significant influence on IP. That is, the greater the cognitive anxiety in college students, the greater their tendency to experience IP. This is in line with Chandra et. al (2019) IP can create a mindset that is difficult to change, such as worried that something bad will happen (fear of failure), can not receive recognition or praise (discounting), fear of being judged by others (Clance \& Toole, 1987). Thus, it is undeniable that IP arises from an irrational belief or fixed mindset that can lead to uncontrollable worry or anxiety (Chandra et al., 2019).

In this study, the behavioral aspect shows a significant influence. Therefore, the greater the behavioral aspect of anxiety, the greater the student's experience with IP. This variable aims to explain the behavior when anxiety occurs. Behaviors such as doing more work than usual, not being able to complete work or tasks, or doing repetitive things to obtain satisfactory results. This is in line with research by Chandra et al. (2019) they stated that people with IP tend to procrastinate or overwork. Eventually, these behaviors form a cycle (Clance and Toole, 1987).

Next is the extraversion trait has a significant coefficient on IP. This finding implies that the lower the extraversion trait in students' personalities, the more likely they are to have IP. This is consistent with the research of Ross et al. (2001). The anxiety experienced by people (who experience IP) prevents them from participating in social circles. According to Clance et al. (1995) people with IP perceive interpersonal interactions as a threat, especially if they interact with people who are more competent than themselves. This proves that people experiencing IP tend to lack the confidence to present themselves because they are afraid of being judged by others (Langford and Clance, 1993).

In this study, the conscientiousness trait shows the most significant coefficient result (see Table 4). This is in line with Bernard et al. (2002), Ross et al. (2001), and Vergauwe et al. (2014) Therefore, the lower the conscientiousness trait in a student's personality, the more prone to experience IP. Lack of discipline and commitment to the task at hand causes people who experience IP to often experience burnout (Chae, Piedmont, \& Estadt, 1995; Chandra et al., 2019). It is undeniable that people who have low conscientiousness tend to be neglectful and incompetent in doing something. Inconsistency in doing something causes people with IP to question whether they are truly competent, regardless of their intelligence or ability.

Agreeableness trait in this study did not quite achieve significance ( $>0.05)$. This result is consistent with Bernard et al. (2002) and Ross et al. (2001). This could be biased by the sample's gender distribution among females up to $78.13 \%$ and among males only $21.86 \%$ of the total sample, which makes the dimensions in this study do not affect IP. Trait agreeableness affects gender, i.e., women have higher agreeableness scores than men (Weisberg, Y. J., DeYoung, C. G., \& Hirsh, J. B., 2011).

In this study, neuroticism from Big-five personality traits, surprisingly, is not statistically significant. This result is different compared to some research conducted by Bernard et al. (2002), Ross et al. (2001), and Vergauwe et al. (2014) which states that neuroticism is a significant personality towards IP. Samples' condition while filled out this questionnaire might be a reason. For this finding, we try to explain the definition of neuroticism itself. Neuroticism is one of the personality traits (Mischel et al., 2008), neuroticism has quite a similar definition and characteristic with the emotional aspect of generalized 
anxiety variable, which is essentially a lack of emotional regulation in individuals, but the difference is emotional in generalized anxiety is a condition of anxious feeling for about past six months (Bystritsky et al., 1990). As the definition before seems to attest that the sample did not claim that they were having emotional dysregulation, but they recently experienced emotional dysregulation than usual. Another study to strengthen this assumption is that individuals who are intellectually and emotionally intelligent need the evaluation by others to assess their lack of awareness of understanding their own emotions (Ghorbanshirodi, 2012).

The openness trait is not statistically significant and consistently similar to previous studies. This indicated from several studies showing that the personality trait of openness has no significant effect on IP (Bernard et al., 2002; Ross et al., 2001; Vergauwe et al., 2014). On the other hand, several studies above had negative directions unlike in this study (see Table 4). It means, the higher the openness trait in individuals, the more chance they experience IP. Research by Chae et al. (1995) on openness trait and IP showed a significant positive correlation in imagination-aesthetics indicator, especially in females. In this study, females had dominated the sample $(78.13 \%)$ than males $(21.86 \%)$. Therefore, why this study does not align with previous research is because of the imbalance between male and female samples. Moreover, in the latest research, openness has a correlation with procrastination or easy distraction by new things, especially in females (Dominguez-lara, Prada-chapoñan, Moreta-herrera, \& Moreta-herrera, 2019; Sandhya \& Gopinath, 2019).

In this study, the family relationships variables in the aspects of cohesion, expressiveness, and conflict are not significant for IP. This is different from research conducted by Bussotti (cited by Sakulku \& Alexander, 2011) and Hawbam \& Singh (2018), but consistently has a positive and negative correlation. The lower the aspects of cohesiveness and expressiveness that students experience with their parents, the greater the experience of IP. On the conflict dimension, the more intense conflict they experience with their parents, the more they experience IP. The sample imbalance between females $(78.13 \%)$ and males $(21.86 \%)$ may explain why the family relationships variable is not significant for IP. Shek (cited by Leung Ling et al., 2019) men need more closeness with their parents to build a good self-image. Besides not only family relationships, but also birth order, gender, parenting style, and the role of children in the family are important in strengthening the influence on IP (Li, Hughes, \& Thu, 2014).

Based on the results of this study, there are some limitations and gaps in this study, including gender imbalance of the sample that makes several dimensions insignificant for IP. In addition, the Covid-19 condition caused all data collection to be conducted via an online form. This may lead to respondent bias to do faking good or social desirability. Another limitation in this study is measurement insensitivity to particular cultures, which results in the insignificance of a variable.

Therefore, future studies are needed to improve the limitations of the study. Hence, forthcoming studies can investigate variables of the locus of control, test anxiety, children's role in the family, parenting style, and others.

\section{Conclusion}

Based on the results of data hypothesis testing, it can be concluded that there is a significant effect of family relationships, generalized anxiety, and Big-five personality traits on the impostor phenomenon. In this study, the results of the minor hypothesis test of the regression coefficient of each variable, generalized anxiety (in the emotional, physiological, cognitive, behavioral aspects), and the Big-five personality traits (extraversion and conscientiousness traits) have a significant effect on IP. Cognitive, extraversion, and conscientiousness aspects are the most significant variables on IP. It can be concluded that IP arises from a mindset that is difficult to change, i.e., feeling threatened by being judged by others and creating a sense of insecurity about their abilities. Second, because they feel threatened by others, people experiencing IP tend to withdraw or are not very active in social circles. Third, IP may be based on a lack of discipline and commitment to their work due to a lack of confidence in their abilities. 
Meanwhile, the family relationship variable (cohesiveness, expressiveness, and conflict aspects) and the Big-five personality traits variable (agreeableness, neuroticism, and openness traits) have no significant effect on the impostor phenomenon. These variables have weak significance due to the sample imbalance in this study.

\section{References}

Baryam, N., \& Bilgel, N. (2008). The prevalence and socio-demographic correlations of depression, anxiety and stress among a group of university students. Social Psychiatry Epidemiology, 43(345), 667-672. https://doi.org/10.1007/s00127-008-0345-X

Bernard, N. S., Dollinger, S. J., \& Ramaniah, N. V. (2002). Applying the big-five personality factors to the impostor phenomenon. Journal of Personality Assessment, 78(2), 321-333. https://doi.org/10.1207/S15327752JPA7802_07

Bravata, D., Watts, S., Keefer, A., Madhusudhan, D., Taylor, K., Clark, D., et al. (2019). Prevalence, predictors, and treatment of impostor syndrome: A systematic review. JGIM, 35(4), 1252-1275. https://doi.org/10.1007/s11606-019-05364-1

Bystritsky, A., Lawrence, L. S., \& Ware, J. E. (1990). Development of a multidimensional scale of anxiety. Journal of Anxiety Disorders, 4(2), 99-115. https://doi.org/10.1016/0887$\underline{6185(90) 90002-Q}$

Canning, E., LaCosse, J., \& Kroeper, K. (2019). Feeling Like an Imposter: The Effect of Perceived Classroom Competition on the Daily Psychological Experiences of First-Generation College Students. Social Psychological and Personality Science, 20(10), 1-11. https://doi.org/10.1177/1948550619882032

Chae, J., Piedmont, R. L., \& Estadt, B. K. (1995). Personological Evaluation of Clance's Imposter Phenomenon Scale in a Korean Sample Personological Evaluation of Clance's Impostor Phenomenon Scale in a Korean Sample. Journal of Personality Assessment, 65(3), 468-485. https://doi.org/10.1207/s15327752jpa6503

Chandra, S., Huebert, C. A., Crowley, E., \& Das, A. M. (2019). Impostor Syndrome: Could it be Holding You or Your Mentees Back? Chest, 156(1), 26-32. https://doi.org/10.1016/j.chest.2019.02.325

Chrisman, S. M., Pieper, W. A., Clance, P. R., Holland, C. L., \& Hughes, C. G. (1995). Validation of Clance IP Scale. Journal of Personality Assessment, 65(3), 456- 467.

Clance, P. (1985). The Impostor Phenomenon: Overcoming the Fear that Haunts your Success. Georgia: Peachtree Publisher, Ltd.

Clance, P. R., Dingman, D., Reviere, S. L., \& Stober, D. R. (1995). Impostor Phenomenon in an Interpersonal/Social Context. Women and Therapy, 16(4), 79-96. https://doi.org/10.1300/J015v16n04_07

Clance, P. R., \& Imes, S. A. (1978). The Imposter Phenomenon in High Achieving Women: Dynamics and Therapeutic Intervention. Psychotherapy: Theory, Research \& Practice, 15(3), 241-247. https://doi.org/10.1037/h0086006 
Clance, P. R., \& Toole, M. A. O. (1987). The Imposter Phenomenon. Women and Therapy, 6(3), 5164. https://doi.org/10.1300/J015V06N03

Cokley, K., Mcclain, S., Enciso, A., \& Martinez, M. (2013). An Examination of the Impact of Minority Status Stress and Impostor Feelings on the Mental Health of Diverse Ethnic Minority College Students. Multicultural Counseling and Development, 41(2), 82-95. https://doi.org/10.1002/j.2161- 1912.2013.00029.x

Dominguez-lara, S., Prada-chapoñan, R., Moreta-herrera, R., \& Moreta-herrera, R. (2019). Gender Differences in the Influence of Personality on Academic Procrastination in Peruvian College Students. Acta Colombiana de Psicología, 22(2), 137-147. https://doi.org/10.14718/ACP.2019.22.2.7

Dudău, D. P. (2014). Irrational Beliefs and Impostor Phenomenon among High School Students: A Correlational Model and its Relevance to REBT Practice. Romanian Journal of Cognitive Behavior Therapy and Hypnosis, 1(1), 1-15.

Farrer, L. M., Gulliver, A., Bennett, K., Fassnacht, D. B., \& Griffiths, K. M. (2016). Demographic and Psychosocial Predictors of Major Depression and Generalised Anxiety Disorder in Australian University Students. BMC Psychiatry, 16(241), 1-9. https://doi.org/10.1186/s12888-016-0961-Z

Fok, C. C. T., Allen, J., Henry, D., \& Team, P. A. (2014). The Brief Family Relationships Scale: A Brief Measure of the Relationships Dimension in Family Functioning. Assessment, 2(1), 6772. https://doi.org/10.1177/1073191111425856

Ghorbanshirodi, S. (2012). The Relationships between Self-Esteem and Emotional Intelligence with Imposter Syndrome among Medical Students of Guilan and Heratsi Universities. Journal of Basic and Applied Scientific Research, 2(2), 1793-1802. Retrieved from www.textroad.com

Harvey, J., \& Katz, C. (1985). If I'm So Successful Why Do I Feel Like a Fake? St. Martin Press.

Hawbam, S., \& Singh, S. (2018). Impostor Phenomenon: Gender Differences and Role of Family Environment. Research Journal of Social Science \& Management, 8(4), 1-8. Retrieved from www.theinternationaljournal.org

Hawley, K., \& Paul, S. K. (2019). Impostor Syndrome. Aristotelian Society Supplementary, 93(1), 203-226. https://doi.org/10.1093/arisup/akz003

Hoang, Q. (2013). The Impostor Phenomenon: Overcoming Internalized Barriers and Recognizing Achievements. The Vermont Connection, 34(6), 42-51. Retrieved from https://scholarworks.uvm.edu/tvc

John, O. P., Naumann, L. P., \& Soto, C. J. (2008). Handbook of Personality: Theory and Research (3rd ed.). The Guillford Press.

Kemendikbud. (n.d) Penyemu. (n.d). In KBBI-V's online dictionary. Retrieved, Mei 2020 from https://kbbi.kemdikbud.go.id/entri/penyemu

Kumar, S., \& Jagacinski, C. M. (2006). Imposters Have Goals Too: The Imposter Phenomenon and its Relationships to Achievement Goal Theory. Personality and Individual Difference, 40(1), 147-157. https://doi.org/10.1016/j.paid.2005.05.014 
Langford, J., \& Clance, P. R. (1993). The Impostor Phenomenon: Recent Research Findings Regarding Dynamics, Personality and Family Patterns and Their Implications for Treatment. Psychotherapy, 30(3), 495-501. https://doi.org/10.1037/0033-3204.30.3.495

Leary, M. R., Patton, K. M., Orlando, A. E., \& Funk, W. W. (2000). The Impostor Phenomenon: SelfPerceptions, Reflected Appraisals, and Interpersonal Strategies. Journal of Personality, 68(4), 725-756. https://doi.org/10.3389/fpsyg.2019.00671

Leung-Ling, M. T. W., Chen, H. F., \& Chiu, K. C. N. (2019). Parental Warmth and Involvement and the Self-Esteem of Young People in Hong Kong. Child Indicators Research. https://doi:10.1007/s12187-019-09645-3

Li, S., Hughes, J., \& Thu, S.M. (2014). The Links Between Parenting Styles and Imposter Phenomenon. Psi Chi Journal of Psychological Research, 19(2), 50-57. doi: 10.24839/21648204.JN19.2.50

Liu, X., Ping, S., \& Gao, W. (2019). Changes in Undergraduate Students' Psychological Well-Being as They Experience University Life. International Journal of Environmental Research and Public Health, 16(2864), 1-14. https://doi.org/doi:10.3390/ijerph16162864

Lobsang, R., Bystritsky, A., Dafter, R. E., \& Spearman, M. (2015). New Strategies for Combining Mindfulness with Integrative Cognitive Behavior Therapy for the Treatment of Generalized Anxiety Disorder. Journal of Rational-Emotive and Cognitive-Behavior Therapy, 29(2), 92119. https://doi.org/10.1007/s10942- 009-0095-Z

Mirsu-Paun, A. (2004). Family Environment Types and Their Association with Family Support Satisfaction among African American and Caucasian American Women with Breast Cancer. (Master's thesis, University of Florida, Florida, US).

McDowell, W. C., Boyd, N. G., \& Bowler, W. M. (2007). Overreward and the Impostor Phenomenon. Journal of Managerial Issues, 19(1), 95-110. Retrieved from https://www.jstor.org/stable/40601195

Mischel, W., Shoda, Y., \& Ayduk, O. (2008). Introduction to Personality (8th ed.). New Jersey: John Willey \& Sons.

Nishihara, N., Belgiawan, P. F., Kim, J., Schmöcker, J.-D., \& Axhausan, K. W. (2017). Identifying the Relationships between Parents' and Child's Car Attitudes: for Long-Term Management of Car Ownership. 17th Swiss Transport Research Conference, 1-26. https://doi.org/10.3929/ethz-b000130803

Parkman, A. (2016). The Imposter Phenomenon in Higher Education: Incidence and Impact. Journal of Higher Education Theory and Practice, 16(1978), 51-60.

Rohrmann, S., Bechtoldt, M.N., \& Leonhardt, M. (2016). Validation of the Impostor Phenomenon among Managers. Frontiers in Psychology, 7(821). https://doi.org/10.3389/fpsyg.2016.00821

Ross, S. R., Stewart, J., Mugge, M., \& Fultz, B. (2001). The Imposter Phenomenon, Achievement Dispositions, and the Five Factor Model. Personality and Individual Differences, 31(8), 13471355. 
Sakulku, J., \& Alexander, J. (2011). The Impostor Phenomenon. International Journal of Behavior Science, 6(1), 75-97.

Sandhya, M., \& Gopinath, T. (2019). The Relationships Study of Big-five Model of Personality and Procrastination among Young Adults. IOSR Journal of Humanities and Social Science, 24(8), 44-55. https://doi.org/10.9790/0837- 2408074455

Sapp, R. L. (2003). Family Conflict and Family Cohesion: Their Relationships to Youths' Behavior Problems. [Doctoral thesis]. University of Tennessee. Retrieved from https://trace.tennessee.edu/utk_graddiss/2375

Sightler, K. W., \& Wilson, M. G. (2001). Correlates of the impostor phenomenon among undergraduate entrepreneurs. Psychological Reports, $88(3), \quad 679-689$. https://doi.org/10.2466/pr0.88.3.679-689

Sonnak, C., \& Towell, T. (2001). The impostor phenomenon in British university students: Relationshipss between self-esteem, mental health, parental rearing style, and socioeconomic status. Personality and Individual Differences, 31, 863-874. doi:10.1016/S01918869(00)00184-7

Stoessel, P. W., Bystritsky, A., \& Pasnau, R. O. (1995). Screening for anxiety disorders in the primary care setting. Family Practice, 12(4), 448-451. https://doi.org/10.1093/fampra/12.4.448

Thompson, T., Davis, H., \& Davidson, J. (1997). Attributional and affective responses of impostors to academic success and failure outcomes. Personality and Individual Differences, 25(2), 381-396. https://doi.org/https://doi.org/10.1016/S0191-8869(98)-00065-8

Vergauwe, J., Wille, B., Feys, M., Fruyt, F. D., \& Anseel, F. (2014). Fear of being exposed: The traitrelatedness of the impostor phenomenon and its relevance in the work context. Journal of Business and Psychology, 30(3), 565-581. https://doi.org/10.1007/s10869-014-9382-5

Weisberg, Y. J., DeYoung, C. G., \& Hirsh, J. B. (2011). Gender differences in personality across the ten aspects of the big-five. Frontiers in Psychology, 2. https://doi:10.3389/fpsyg.2011.00178

Wulandari, A., \& Tjundjing, S. (2007). Impostor phenomenon, self-esteem, dan self-efficacy. Anima Indonesian Psychological Journal, 23(1), 63-67. 